ARTIKEL PENELITIAN

\title{
PENGARUH PENYULUHAN METODE CERAMAH DAN AUDIO-VISUAL TERHADAP PENGETAHUAN IBU HAMIL TENTANG 1000 HPK DI PUSKESMAS SIDOMULYO RAWAT INAP KOTA PEKANBARU
}

\author{
Melly $^{1)}$, Magdalena ${ }^{2}$ \\ ${ }^{1) 2)}$ Keperawatan, Poltekkes Kemenkes Riau, Jl. Melur No. 103, Pekanbaru, 28122 \\ Email: mellykamal28@gmail.com
}

\begin{abstract}
The first 1000 days of Life is a movement acceleration improvement of nutrition are set by the Government of Indonesia to address the problem of nutrition. The purpose of this research is to know the influence of extension with lectures and audio-visual methods against the level of knowledge of pregnant women about The first 1000 days of Life on the Community Health Center Sidomulyo Pekanbaru. This research uses quasi-experimental design one group pretest-posttest design. Sample as many as 22 pregnant women First until third trimesther to visit Clinics Sidomulyo Inpatient Pekanbaru. The results showed the level of knowledge of respondents before the extension is done using the method of lecturing categories include both have 5 people $(45.5 \%)$ respondents, and that includes the categories is not good there are 6 people $(54.5 \%)$ while the level of knowledge the respondents after were done using methods extension lectures including categories either have 6 people $(54.5 \%)$ and which includes the category of no good there were 5 people (45.5\%). Level of knowledge of respondents before the extension is done using audio-visual methods include good category there are 7 persons $(63.6 \%)$ and which includes categories is not good there are 4 people (36.4\%) while the level of knowledge of respondents having done extension method using audio-visual categories include both have 6 people $(54.5 \%)$ and which includes the category of no good there were 5 people $(45.5 \%)$. Audio-visual methods extension (video) more influential lecture method compared to the difference between the before and after done extension i.e. of 27.18.
\end{abstract}

Keywords: Education, Knowledge Of The Mother, The first 1000 days of Life

\begin{abstract}
Abstrak
Gerakan 1000 Hari Pertama Kehidupan (HPK) adalah suatu gerakan percepatan perbaikan gizi yang ditetapkan oleh pemerintah Indonesia untuk menjawab permasalahan gizi. Tujuan penelitian ini adalah untuk mengetahui pengaruh penyuluhan dengan metode ceramah dan audio visual terhadap tingkat pengetahuan ibu hamil tentang seribu hari pertama kehidupan di Puskesmas Sidomulyo Rawat Inap Kota Pekanbaru Tahun 2017. Penelitian ini menggunakan rancangan quasi-experimental one group pretestposttest design. Sampel sebanyak 22 orang Ibu Hamil Trimester I s/d III yang berkunjung ke Puskesmas Sidomulyo Rawat Inap Kota Pekanbaru. Hasil penelitian menunjukkan tingkat pengetahuan responden sebelum dilakukan penyuluhan menggunakan metode ceramah termasuk kategori baik ada 5 orang $(45,5 \%)$ responden, dan yang termasuk kategori tidak baik ada 6 orang $(54,5 \%)$ sedangkan tingkat pengetahuan responden setelah dilakukan penyuluhan menggunakan metode ceramah termasuk kategori baik ada 6 orang $(54,5 \%)$ dan yang termasuk kategori tidak baik ada 5 orang (45,5\%). Tingkat pengetahuan responden sebelum dilakukan penyuluhan menggunakan metode audio visual termasuk kategori baik ada 7 orang $(63,6 \%)$ dan yang termasuk kategori tidak baik ada 4 orang $(36,4 \%)$ sedangkan tingkat pengetahuan responden sesudah dilakukan penyuluhan menggunakan metode audio visual termasuk kategori baik ada 6 orang $(54,5 \%)$ dan yang termasuk kategori tidak baik ada 5 orang (45,5\%).Penyuluhan dengan Metode audio visual (video) lebih berpengaruh dibandingkan dengan metode ceramah yaitu dengan selisih antara sebelum dan sesudah dilakukan penyuluhan yaitu sebesar 27,18 .
\end{abstract}

Kata Kunci : Penyuluhan, Pengetahuan Ibu, Seribu Hari Pertama Kehidupan 


\section{PENDAHULUAN}

Gerakan 1000 Hari Pertama

Kehidupan (HPK) adalah suatu gerakan percepatan perbaikan gizi yang ditetapkan oleh pemerintah Indonesia untuk menjawab permasalahan gizi. Perbaikan gizi yang baik selama periode 1000 hari dimulai awal kehamilan sampai ulang tahun kedua anak sangat penting untuk masa depan kesehatan, kesejahteraan dan kesuksesan anak. Gizi yang tepat pada periode ini memberi dampak besar pada kemampuan anak untuk tumbuh, belajar, dan bangkit dari keterpurukan.

Periode 1000 Hari Pertama Kehidupan secara ilmiah merupakan periode yang menentukan kualitas kehidupan yang sering disebut sebagai periode emas. 1000 HPK merupakan periode sensitive karena dampak yang ditimbulkan akan bersifat permanen dan tidak dapat dikoreksi.

Dampak tersebut tidak hanya pada pertumbuhan fisik, tetapi juga pada perkembangan mental dan kecerdasan, dan pada usia dewasa akan terlihat dari ukuran fisik yang tidak optimal serta kualitas kerja yang tidak kompetitif berakibat pada rendahnya produktivitas dan ekonomi (Kemenko Kesra RI, 2012). Permasalahan gizi yang masih terjadi di Indonesia harus segera diatasi mengingat dampaknya yang sangat besar bagi kelangsungan hidup suatu bangsa. Masalah gizi yang terjadi pada kelompok 1000 Hari Pertama Kehidupan saat ini semakin memprihatinkan baik masalah gizi pada ibu hamil maupun pada balita. Adapun masalah gizi yang sering terjadi pada ibu hamil adalah Kurang Energi Kronis (KEK) dan anemia.

Berdasarkan data Riskesdas (2013) prevalensi ibu hamil KEK usia 15-19 tahun adalah $38,5 \%$ dan prevalensi anemia pada ibu hamil yaitu $37,1 \%$. Hal ini berbanding lurus dengan semakin meningkatnya masalah gizi pada balita yaitu terdapat 19,6\% balita gizi kurang dan $37,2 \%$ balita pendek (stunting). Profil Kesehatan Propinsi Riau Tahuh 2007 Prevalensi Status Gizi Balita Berdasarkan BB/U Propinsi Riau Tahun 2007 Gizi Kurang, 11.8\% Gizi Baik, 83.5\% Gizi Lebih, 1.4\% Gizi Buruk, $3.3 \%$. Berdasarkan hasil studi yang di dilakukan terhadap 10 orang Ibu hamil di Puskesmas Sidomulyo Rawat Inap Kota Pekanbaru didapatkan data: hanya 2 orang dari $10 \mathrm{ibu}$ hamil yang mengetahui tentang seribu hari pertama kehidupan. Berdasarkan latar belakang dan fenomena tersebut di atas, peneliti 
merasa tertarik untuk mengetahui "Pengaruh Penyuluhan dengan metode 1. Analisis Univariat ceramah dan audio visual terhadap Tingkat Pengetahuan Ibu Hamil tentang Seribu Hari Pertama Kehidupan di Puskesmas Sidomulyo Rawat Inap Kota Pekanbaru Tahun 2017”.

\section{METODE PENELITIAN}

Metode penelitian ini menggunakan rancangan quasi-experimental one group pretest-posttest design. Waktu penelitian ini dilaksanakan pada bulan 14 Oktober s/d 01 Nopember tahun 2017 dan tempat penelitian penelitian ini dilaksanakan di Puskesmas Rawat Inap Sidomulyo Kota Pekanbaru. Populasi dalam penelitian ini adalah semua Ibu Hamil Trimester I s/d III yang berkunjung ke Puskesmas Rawat Inap Kota Pekanbaru. Jumlah sampel pada penelitian ini berjumlah 22 orang ibu hamil.

\section{HASIL DAN PEMBAHASAN}

Hasil Penelitian ini diperoleh dari hasil pengukuran tingkat pengetahuan ibu hamil tentang seribu hari pertama kehidupan melalui penyuluhan yang diberikan dengan metode ceramah dan metode audio visual.

\begin{tabular}{ccc}
\hline Umur & Frekuensi & Persentase \\
\hline 20Tahun & 2 & $9,1 \%$ \\
21Tahun & 2 & $9,1 \%$ \\
22Tahun & 2 & $9,1 \%$ \\
24 Tahun & 3 & $13,6 \%$ \\
25 Tahun & 1 & $4,5 \%$ \\
26 Tahun & 1 & $4,5 \%$ \\
27 Tahun & 2 & $9,1 \%$ \\
28 Tahun & 2 & $9,1 \%$ \\
30 Tahun & 2 & $9,1 \%$ \\
31 Tahun & 1 & $4,5 \%$ \\
32 Tahun & 1 & $4,5 \%$ \\
33 Tahun & 2 & $9,1 \%$ \\
34 Tahun & 1 & $4,5 \%$ \\
\hline Jumlah & 22 & $100 \%$ \\
\hline
\end{tabular}

Berdasarkan Tabel 5.1 menunjukkan bahwa sebagian besar responden pada penelitian ini berumur 24 tahun sebanyak 3 orang $(13,6 \%)$.

Tabel 5.2

Distribusi Frekuensi Responden

Berdasarkan Pendidikan

diPuskesmas Sidomulyo Rawat Inap Kota Pekanbaru Tahun 2017

\begin{tabular}{lll}
\hline Pendidikan & Frekuensi & Persentase \\
\hline SD & 3 & $13,6 \%$ \\
SMP & 6 & $27,3 \%$ \\
SMA & 12 & $54,5 \%$ \\
PT & 1 & $4,5 \%$ \\
\hline Jumlah & 22 & $100 \%$ \\
\hline
\end{tabular}

Berdasarkan Tabel 5.2 menunjukkan bahwa sebagian besar responden 
mempunyai pendidikan tingkat SMA

sebanyak 12 orang $(54,5 \%)$

Tabel 5.3

Distribusi Frekuensi Responden Berdasarkan Pekerjaan diPuskesmas Sidomulyo Rawat Inap Kota Pekanbaru Tahun 2017

\begin{tabular}{lll}
\hline Pekerjaan & Frekuensi & Persentase \\
\hline Tidak Bekerja & 21 & $95,5 \%$ \\
Bekerja & 1 & $4,5 \%$ \\
\hline Jumlah & 22 & $100 \%$ \\
\hline
\end{tabular}

Berdasarkan Tabel 5.3 menunjukkan bahwa sebagian besar responden pada penelitian ini tidak bekerja sebanyak 21 orang $(95,5 \%)$.

Tabel 5.4

Distribusi Frekuensi Gambaran Pengetahuan Ibu Hamil Tentang Seribu Hari Pertama KehidupandiPuskesmas Sidomulyo Rawat Inap Kota Pekanbaru Tahun 2017

\begin{tabular}{lll}
\hline $\begin{array}{l}\text { Pengetahua } \\
\text { n }\end{array}$ & $\begin{array}{l}\text { Frekuens } \\
\text { i }\end{array}$ & $\begin{array}{l}\text { Persentas } \\
\text { e }\end{array}$ \\
\hline Baik & 9 & $40,9 \%$ \\
Kurang & 13 & $59,1 \%$ \\
\hline Jumlah & 22 & $100 \%$ \\
\hline
\end{tabular}

Berdasarkan Tabel 5.4 menunjukkan bahwa sebagian besar responden pada penelitian ini mempunyai pengetahuan kurang sebanyak 13 orang $(59.1 \%)$.

\section{Tabel 5.5}

Distribusi Frekuensi Gambaran

Pengetahuan Responden

Dengan Metode Ceramah diPuskesmas Sidomulyo Rawat Inap Kota Pekanbaru Tahun 2017

\begin{tabular}{cccc}
\hline No & Sebelum & Sesudah & Selisih \\
\hline $\mathbf{1}$ & 40 & 55 & 15 \\
$\mathbf{2}$ & 23 & 23 & 0 \\
$\mathbf{3}$ & 27 & 27 & 0 \\
$\mathbf{4}$ & 55 & 55 & 0 \\
$\mathbf{5}$ & 18 & 32 & 14 \\
$\mathbf{6}$ & 50 & 36 & -14 \\
$\mathbf{7}$ & 41 & 45 & 4 \\
$\mathbf{8}$ & 55 & 68 & 13 \\
$\mathbf{9}$ & 86 & 77 & -9 \\
$\mathbf{1 0}$ & 80 & 81 & 1 \\
$\mathbf{1 1}$ & 77 & 86 & 9 \\
\hline
\end{tabular}

Berdasarkan tabel 5.5 hasil pengukuran pengetahuan terhadap 11 responden dengan metode ceramah didapatkan hasil bahwa perubahan pengetahuan sebelum dan sesudah dilakukannya penyuluhan pada responden dengan metode ceramah, sebanyak 6 orang responden mengalami kenaikan, 3 orang responden tidak mengalami kenaikan dan 2 orang mengalami penurunan pengetahuan setelah dilakukan penyuluhan dengan metode ceramah

Tabel 5.6

Distribusi Frekuensi Gambaran Pengetahuan Responden Dengan Metode Audio Visual diPuskesmas Sidomulyo Rawat Inap Kota Pekanbaru Tahun 2017 $(n=11)$

\begin{tabular}{llll}
\hline No & Sebelum & Sesudah & Selisih \\
\hline $\mathbf{1}$ & 73 & 82 & 9 \\
$\mathbf{2}$ & 36 & 77 & 41 \\
$\mathbf{3}$ & 55 & 90 & 35 \\
$\mathbf{4}$ & 27 & 68 & 41 \\
$\mathbf{5}$ & 55 & 77 & 22 \\
$\mathbf{6}$ & 36 & 63 & 27 \\
$\mathbf{7}$ & 63 & 100 & 37 \\
\hline
\end{tabular}




\begin{tabular}{llll}
\hline $\mathbf{8}$ & 59 & 90 & 31 \\
$\mathbf{9}$ & 63 & 91 & 28 \\
$\mathbf{1 0}$ & 40 & 64 & 24 \\
$\mathbf{1 1}$ & 77 & 81 & 4 \\
\hline
\end{tabular}

Berdasarkan tabel 5.6 hasil pengukuran terhadap 11 responden dengan metode audio visual didapatkan hasil bahwa perubahan

Tabel 5.7

Uji Normalitas Data Responden diPuskesmas Sidomulyo Rawat Inap Kota Pekanbaru Tahun 2017

\begin{tabular}{llll}
\hline & \multicolumn{3}{l}{$\begin{array}{l}\text { Uji Skewness dan Standar } \\
\text { Erornya }\end{array}$} \\
\cline { 2 - 4 } & \multicolumn{2}{l}{$\begin{array}{l}\text { Metode Ceramah dan Metode } \\
\text { Audio Visual }\end{array}$} \\
\cline { 2 - 4 } & Skewness & Std. Eror & Hasil \\
\hline Sebelum & 0,40 & 0,491 & 0,814 \\
\hline Sesudah & $-0,629$ & 0,491 & $-1,281$ \\
\hline
\end{tabular}

Berdasarkan tabel 5.7 dapat dilihat bahwa uji normalitas data pengetahuan responden sebelum dan sesudah penyuluhan menunjukkan hasil pembagian nilai skewness dengan standar errornya menghasilkan nilai < 2, maka data dikatakan berdistribusi normal.

Dari hasil tersebut maka selanjutnya dilakukan uji statistic parametrik, yaitu uji $t$ dependen untuk menilai perubahan yang terjadi pada pengetahuan sesudah dilakukannya penyuluhan, dilakukan uji beda rata-rata pada data pengetahuan responden

Tabel 5.9

Distribusi Frekuensi Gambaran Pengetahuan Responden Sesudah Dilakukan Penyuluhan Menggunakan Metode Ceramah
pengetahuan sebelum dan sesudah dilakukannya penyuluhan pada responden dengan metode audio visual, sebanyak11 orang responden mengalami kenaikan setelah dilakukan penyuluhan dengan metode audio visual.

dengan penyuluhan metode ceramah dan metode audio visual diterangkan pada tabel 5.7.

Tabel 5.8

Distribusi Frekuensi Gambaran

Pengetahuan Responden Sebelum

Dilakukan Penyuluhan Menggunakan Metode Ceramah

\begin{tabular}{cccc}
\hline No & $\begin{array}{c}\text { Kategori } \\
\text { Pengetahuan }\end{array}$ & $\begin{array}{c}\text { Frekue } \\
\text { nsi }\end{array}$ & Persentase \\
\hline $\mathbf{1}$ & Baik & 5 & $45,5 \%$ \\
$\mathbf{2}$ & Tidak Baik & 6 & $54,5 \%$ \\
\hline & Jumlah & 11 & 100 \\
\hline
\end{tabular}

Berdasarkan tabel 5.8 dapat dilihat bahwa tingkat pengetahuan responden sebelum dilakukan penyuluhan menggunakan metode ceramah termasuk kategori baik ada 5 orang $(45,5 \%)$ responden, dan yang termasuk kategori tidak baik ada 6 orang $(54,5 \%)$ responden.

diPuskesmas Sidomulyo Rawat Inap Kota Pekanbaru Tahun $2017(n=10)$

\begin{tabular}{llll}
\hline No & Kategori & Frekuens & Persent \\
Pengetahua & i & ase \\
n & & \\
\hline
\end{tabular}




\begin{tabular}{llll}
\hline $\mathbf{1}$ & Baik & 6 & $54,5 \%$ \\
$\mathbf{2}$ & Tidak Baik & 5 & $45,5 \%$ \\
\hline & Jumlah & 11 & 100 \\
\hline
\end{tabular}

Berdasarkan tabel 5.9 dapat dilihat bahwa tingkat pengetahuan responden setelah dilakukan penyuluhan menggunakan metode ceramah termasuk kategori baik ada 6 orang $(54,5 \%)$ responden, dan yang termasuk kategori tidak baik ada 5 orang $(45,5 \%)$ responden.

Tabel 5.10

Distribusi Frekuensi Gambaran Pengetahuan Responden

Sebelum Dilakukan Penyuluhan Menggunakan Metode Audio Visual diPuskesmas Sidomulyo Rawat Inap Kota Pekanbaru Tahun $2017(\mathrm{n}=11)$

\begin{tabular}{cccc}
\hline No & $\begin{array}{c}\text { Kategori } \\
\text { Pengetahuan }\end{array}$ & $\begin{array}{c}\text { Frekue } \\
\text { nsi }\end{array}$ & $\begin{array}{c}\text { Persen } \\
\text { tase }\end{array}$ \\
\hline $\mathbf{1}$ & Baik & 7 & $63,6 \%$ \\
$\mathbf{2}$ & Tidak Baik & 4 & $36,4 \%$ \\
\hline & Jumlah & 11 & 100 \\
\hline
\end{tabular}

Berdasarkan tabel 5.10 dapat dilihat bahwa tingkat pengetahuan responden

2. Analisis Bivariat

Pengaruh penyuluhan dengan metode ceramah dan audio sebelum dilakukan penyuluhan menggunakan metode audio visual termasuk kategori baik ada 7 orang $(63,6 \%)$ responden, dan yang termasuk kategori tidak baik ada 4 orang $(36,4 \%)$ responden.

tabel 5.11

Distribusi Frekuensi Gambaran Pengetahuan Responden Sesudah Dilakukan Penyuluhan Menggunakan Metode Audio Visual

\begin{tabular}{cccc}
\hline No & $\begin{array}{c}\text { Kategori } \\
\text { Pengetahuan }\end{array}$ & Frekuensi & $\begin{array}{c}\text { Persenta } \\
\text { se }\end{array}$ \\
\hline 1 & Baik & 6 & $54,5 \%$ \\
2 & Tidak Baik & 5 & $45,5 \%$ \\
\hline
\end{tabular}

Berdasarkan table 5.11 dapat dilihat bahwa tingkat pengetahuan responden sesudah dilakukan penyuluhan menggunakan metode audio visual termasuk kategori baik ada 6 orang $(54,5 \%)$ responden, dan yang termasuk kategori tidak baik ada 5 orang $(45,5 \%)$ responden.

visual terhadap tingkat pengetahuan tentang seribu hari pertama kehidupan.

Tabel 5.12

Distribusi Pengetahuan Responden Sebelum dan Sesudah dilakukan Penyuluhan Menggunakan Metode Ceramah dengan Metode AudioVisual

\begin{tabular}{ccccc}
\hline Variabel & $\begin{array}{c}\text { Mean (SD) } \\
\text { Sebelum } \\
\text { penyuluhan }\end{array}$ & $\begin{array}{c}\text { Mean (SD) } \\
\text { Sesudah } \\
\text { penyuluhan }\end{array}$ & Beda Mean & P value \\
& & \\
\hline
\end{tabular}




\begin{tabular}{lllll}
\hline Metode ceramah & $50,18 \pm$ & $53,18 \pm$ & 3 & 0,310 \\
& 23,319 & 22,476 & & \\
\hline Metode audio & $53,09 \pm$ & $80,27 \pm$ & 27,18 & 0,000 \\
& 16,257 & 11,967 & & \\
\hline
\end{tabular}

Berdasarkan tabel 5.12 hasil uji menggunakan metode video visual yaitu statistic vaired t- test didapatkan nilai rata- 80,27 dengan SD 11,967, metode audio rata sebelum dilakukan penyuluhan visual menunjukkan hasil nilai $p$ value < menggunakan metode ceramah yaitu nilai alpha 0,05 maka disimpulkan ada 50,18 dengan SD 23,319 dan nilai rata- perbedaan yang signifikan antara rata setelah dilakukan penyuluhan pengetahuan sebelum dan sesudah menggunakan metode ceramah yaitu dilakukan penyuluhan dengan metode 53,18 dengan SD 22,476, metode ceramah audio visual.

menunjukkan hasil nilai $p$ value > nilai

Hal ini menunjukan bahwa metode alpha 0,05 maka disimpulkan tidak ada audio visual (video) lebih berpengaruh perbedaan yang signifikan antara dibandingkan dengan metode ceramah pengetahuan sebelum dan sesudah yaitu dengan selisihan antara sebelum dan dilakukan penyuluhan dengan metode sesudah dilakukan penyuluhan yaitu ceramah. Sedangkan nilai rata-rata sebesar 27,18 sedangkan metode ceramah sebelum dilakukan penyuluhan dengan selisih antara sebelum dan sesudah menggunakan metode video visual yaitu yaitu 3. Dari penjelasan di atas metode 53,09 dengan SD 16,257dan nilai rata- video lebih efektif dari pada metode rata setelah dilakukan penyuluhan ceramah yaitu dengan selisih 24,18.

\section{PEMBAHASAN}

A. Karakteristik Responden

\section{Umur}

Dari hasil penelitian menunjukkan bahwa mayoritas ibu hamil berusia 24 tahun sebanyak 3 orang $(13,6 \%)$ termasuk dalam kategori dewasa awal. Responden dalam penelitian ini yaitu ibu hamil terbanyak pada usia 24 tahun yang mana dapat menggambarkan kematangan seseorang,baik secara fisik, dan sosial. Dengan bertambahnya umur seseorang akan mengalamiperubahan aspek fisik dan psikologis (mental), Pada aspek psikologisatau mental, taraf berfikir seseorang menjadi semakin matang dandewasa (Mubarok, 2011). Semakin tinggi umur seseorang semakin 
bertambah pula ilmu atau pengetahuan yang dimiliki (Notoatmodjo, 2010).

2. Pendidikan

Berdasarkan Tabel 5.2 sebagian besar menunjukkan bahwa responden mempunyai pendidikan tingkat SMA sebanyak 12 orang $(54,5 \%)$.

Pada penelitian ini, ibu hamil sebagian besar mempunyai pendidikan tingkat SMA sebanyak 12 Orang $(54,5 \%)$ di Puskesmas Sidomulyo Rawat Inap Kota Pekanbaru mayoritas berpendidikan SMA hal ini sesuai dengan teori Notoatmodjo (2010) yang menyatakan bahwa pendidikan yang rendah akan menghambat perkembangan terhadap informasi. Pendidikan berarti bimbingan yang diberikan seseorang kepada orang lain agar dapat memahami sesuatu hal (Mubarok, 2011). Semakin tinggi pendidikan seseorang, semakin mudah pula menerima informasi, pengetahuan yang dimilikinya akan semakin banyak. Pendidikan yang rendah akan menghambat perkembangan terhadap informasi.

\section{Pekerjaan}

Berdasarkan Tabel 5.3 menunjukkan bahwa sebagian besar responden pada penelitian ini tidak bekerja sebanyak 21 orang $(95,5 \%)$.
Dari data tersebut menunjukkan bahwa mayoritas responden tidak bekerja (Sebagai Ibur Rumah Tangga). Hasil penelitian mendukung teori Mubarok (2011) yang ada karena sebagian besar ibu hamil tidak bekerja hanya sebagai ibu rumah tangga, sehingga pengalaman dan pengetahuan yang dimiliki menjadi berkurang dan terbatas. Bekerja merupakan kegiatan yang menyita waktu, bekerja bagi ibuibu akan mempunyai pengaruh terhadap kehidupan keluarga Nursalam (2009). Menurut Mubarok (2011) Lingkungan pekerjaan dapat memperoleh pengetahuan dan pengalaman baik secara langsung maupun tidak langsung.

B. Gambaran Pengetahuan Ibu Hamil Tentang Seribu Hari Pertama Kehidupan

1. Pengetahuan ibu hamil metode ceramah sebelum dan sesudah

Berdasarkan tabel 5.4 hasil pengukuran pengetahuan terhadap 11 responden dengan metode ceramah didapatkan hasil bahwa perubahan pengetahuan sebelum dan sesudah dilakukannya penyuluhan pada responden dengan metode ceramah, sebanyak 6 orang responden mengalami kenaikan, 3 
orang responden tidak mengalami kenaikan dan 2 orang mengalami penurunan pengetahuan setelah dilakukan penyuluhan dengan metode ceramah. Hal ini menunjukkan responden bertambah pengetahuan setelah menerima pendidikan kesehatan dengan metode ceramah. Materi dalam ceramah disampaikan dengan menggunakan bahasa yang mudah dimengerti oleh responden. Keuntungan dari metode ceramah dan bahasa yang disampaikan dengan cara mudah dipahami serta adanya komunikasi dua arah antara penyuluh kesehatan dan pertanyaan dari responden menjadikan responden lebih memahami dari materi yang disampaikan oleh penyuluh. Menurut Wawan dan Dewi (2010) faktor yang mempengaruhi tingkat pengetahuan seseorang berasal dari informasi yang diterimanya, dengan sumber informasi yang lebih banyak salah satunya berasal dari petugas kesehatan akan meningkatkan pengetahuan yang lebih luas.

1. Pengetahuan Ibu Hamil Metode Audio Visual Sebelum Dan Sesudah
Berdasarkan tabel 5.5 hasil pengukuran terhadap 11 responden dengan metode audio visual didapatkan hasil bahwa perubahan pengetahuan sebelum dan sesudah dilakukannya penyuluhan pada responden dengan metode audio visual, sebanyak 11 orang responden mengalami kenaikan setelah dilakukan penyuluhan dengan metode audio visual.

Menurut Arsyad (2003) media audiovisual adalah seperangkat alat yang dapat memproyeksikan gambar bergerak dan bersuara, sementara Arsyad menyatakan media audiovisual adalah bahan atau alat yang dipergunakan dalam situasi belajar untuk membantu tulisan dan kata yang diucapkan dalam menularkan pengetahuan, sikap dan ide. Berdasarkan hasil penelitian kelompok audiovisual selama proses penayangan seribu hari pertama kehidupan. Responden menyimak dengan seksama informasi apa saja yang ada di dalam tayangan tersebut.

2. Perbedaan Tingkat Pengetahuan ibu hamil Tentang Seribu Hari Pertama Kehidupan Sebelum Dan Sesudah 
Diberikan Pendidikan Kesehatan Dengan Metode Ceramah

Berdasarkan tabel 5.11 hasil uji statistic vaired t- test didapatkan nilai rata-rata sebelum dilakukan penyuluhan menggunakan metode ceramah yaitu 50,18 dengan SD 23,319 dan nilai rata-rata setelah dilakukan penyuluhan menggunakan metode ceramah yaitu 53,18 dengan SD 22,476, metode ceramah menunjukkan hasil nilai $p$ value > nilai alpha 0,05 maka disimpulkan tidak ada perbedaan yang signifikan antara pengetahuan sebelum dan sesudah dilakukan penyuluhan dengan metode ceramah.Sedangkan nilai rata-rata sebelum dilakukan penyuluhan menggunakan metode video visual yaitu 53,09 dengan SD 16,257 dan nilai rata-rata setelah dilakukan penyuluhan menggunakan metode video visual yaitu 80,27 dengan SD 11,967, metode audio visual menunjukkan hasil nilai $p$ value < nilai alpha 0,05 maka disimpulkan ada perbedaan yang signifikan antara pengetahuan sebelum dan sesudah dilakukan penyuluhan dengan metode audio visual. Hal ini menunjukan bahwa metode audio visual (video) lebih berpengaruh dibandingkan dengan metode ceramah yaitu dengan selisihan antara sebelum dan sesudah dilakukan penyuluhan yaitu sebesar 27,18 sedangkan metode ceramah dengan selisih antara sebelum dan sesudah yaitu 3. Dari penjelasan di atas metode video lebih efektif dari pada metode ceramah yaitu dengan selisih 24,18.

Adanya penggunaan media audiovisual yang digunakan dalam penelitian ini, secara tidak langsung meningkatkan daya ingat responden dibandingkan denagn menggunakan metode ceramah. Penyuluh dalam menyampaikan materi pembelajaran dengan sarana media audio visual, yang disampaikan oleh penyuluh kepada responden cukup menarik dengan film-film pendek. Penyuluh dituntut untuk mampu menjelaskan materi kepada ibu-ibu hami secara professional. Dalam pelaksanaannya penyuluh dapat mengunakan media pembelajaran dan sumber-sumber belajar yang relevan yang berkaitan dengan seribu hari pertama kehidupan.. 


\section{SIMPULAN}

Berdasarkan hasil penelitian yang penulis lakukan maka dapat disimpulkan bahwa :

a. Gambaran Karakteristik responden menurut umur, pendidikan dan pekerjaan bahwa sebagian besar responden pada penelitian ini berumur 24 tahun sebanyak 3 orang $(13,6 \%)$ Berdasarkan pendidikan bahwa sebagian besar responden mempunyai pendidikan tingkat SMA sebanyak 12 orang $(54,5 \%)$ Berdasarkan pekerjaan sebagian besar responden pada penelitian ini tidak bekerja sebanyak 21 orang $(95,5 \%)$.

b. Tingkat pengetahuan responden sebelum dilakukan penyuluhan menggunakan metode ceramah termasuk kategori baik ada 5 orang $(45,5 \%)$ responden, dan yang termasuk kategori tidak baik ada 6 orang $(54,5 \%)$ responden sedangkan tingkat pengetahuan responden setelah dilakukan penyuluhan menggunakan metode ceramah termasuk kategori baik ada 6 orang $(54,5 \%)$ responden, dan yang termasuk kategori tidak baik ada 5 orang $(45,5 \%)$ responden.

c. Tingkat pengetahuan responden sebelum dilakukan penyuluhan menggunakan metode audio visual termasuk kategori baik ada 7 orang $(63,6 \%)$ responden, dan yang termasuk kategori tidak baik ada 4 orang $(36,4 \%)$ responden sedangkan tingkat pengetahuan responden sesudah dilakukan penyuluhan menggunakan metode audio visual termasuk kategori baik ada 6 orang $(54,5 \%)$ responden, dan yang termasuk kategori tidak baik ada 5 orang $(45,5 \%)$ responden.

d. Penyuluhan dengan Metode audio visual (video) lebih berpengaruh dibandingkan dengan metode ceramah yaitu dengan selisihan antara sebelum dan sesudah dilakukan penyuluhan yaitu sebesar 27,18.

\section{UCAPAN TERIMA KASIH}

\section{DAFTAR PUSTAKA}

Badan Perencanaan Pembangunan Nasional, 2012, Pedoman Perencanaan Program Gerakan Sadar Gizi Dalam Rangka Seribu 
Mahakam Midwifery Journal, Vol 2, No. 4, November 2018 : 255-266

Hari Pertama Kehidupan (1000

HPK),Badan Penelitian dan

Pengembangan Nasional, Jakarta

Badan Penelitian dan Pengembangan

Kesehatan, 2013, Riset Kesehatan

Dasar, Kementerian Kesehatan

Republik Indonesia, Jakarta

Dahlan, M.Sopiyudin, 2005, Besar

Sampel untuk Penelitian Kedokteran dan Kesehatan, Arkans, Jakarta

Departemen Kesehatan Republik Indonesia Tahun 2000, diakses pada tanggal 15 Maret 2015

Maulana, H, 2009, Promosi Kesehatan, Jakarta: Buku Kedokteran EGC

Notoatmodjo, Soekidjo, 2007, Promosi Kesehatan dan Ilmu Perilaku, Rineka Cipta, Jakarta

Permatasari, Sylva Medika, 2013, Hubungan Antara Status Gizi dengan Perkembangan

Anak Usia 1000 Hari Pertama Kehidupan,Skripsi, Universitas Sebelas Maret

Sapto, Haryoko. Efektifitas Pemanfaatan Media Audio Visual
Sebagai Alternatif Optimalisasi Model Pembelajaran. 2009. Akses $30 \quad$ Desember 2011. http.journal.uni.ac.id

Soekidjo, Notoadmojo, Promosi Kesehatan. Teori dan Aplikasi. Rineka Cipta : Jakarta. 2010. 